\title{
Karl Marx, Digital Technology, and Liberation Theology
}

\author{
Peter McLaren \\ Co-Director of the Paulo Freire Democratic Project, \\ The Attallah College of Educational Studies, Chapman University \\ mclaren@chapman.edu \\ Petar Jandrić \\ Zagreb University of Applied Sciences, Croatia , Editor-in-Chief, \\ Postdigital Science and Education \\ http://petarjandric.com/
}

\begin{abstract}
Since 2011 Peter McLaren and Petar Jandrić have written a dozen of dialogic articles focused to critical pedagogy in the age of information technology and liberation theology. These articles are packed with Peter McLaren's interpretations of Karl Marx in various contexts, yet they never focused explicitly to McLaren's Marxist thought. In this article we present a collection of Peter McLaren's interpretations of Karl Marx written during 8 years of working together. Developed and published in various contexts, insights in this article do not present a complete overview of Peter McLaren's understanding of Marxism. Yet, focusing to extremely radically different themes of information technology and liberation theology, Peter McLaren's views present a rich source for understanding Marxist theory in the 21st century.
\end{abstract}

\section{Keywords}

Peter McLaren - Karl Marx - digital technology - liberation theology 


\section{Karl Marx and Digital Technology}

PJ: Your early work has been strongly influenced by postmodernism. For more than a decade, however, it has slowly but surely entered "the Marxist-humanist trajectory" spanning from authors with various Marxist tendencies and the neo-Marxism of the Frankfurt School to the original works of Marx (McLaren, McMurry and McGuirk, 2008). The shift from postmodern Peter to Marxist Peter has been elaborated fairly extensively - for instance, in conversations with Marcia Moraes and Glenn Rikowski published in Rage and Hope (2006). Please summarize it in few sentences.

PM: One of the foundational social relations that interdicts a student's access to resources necessary to see the world critically is, I believe, class exploitation. An exploitation that despoils communities and dispossesses workers of their humanity. Education opposes schooling. Education is that which intrudes upon our instincts and instruments of mind and augments them; it pushes us our thoughts along the arcs of the stars where our thoughts can give rise to new vistas of being and becoming and to new solidarities with our fellow humans. Our responsibilities for creating critical citizens should be proportional to our privilege. Today a good education is no longer seen as a social responsibility but as picking carefully from an array of consumer choices provided by a number of new companies and corporations. We now offer endless arrays of remedies for new kinds of learning disabilities. Just take your pick. As early as the 1980s, I was asking myself: How do we react to the cries of help from the youth of today, whose full-throated screams meet the immemorial silence of the pedagogical tradition? An answer to this question mandated a move away from the ironic distantiation and self-indulgent detachment of the vulgar divas of the academy who clearly chose identity politics over class politics (and in so doing became complicitous in the very relations of inequality they officially rejected) by a close reading of Marx and Marxist theorists, culminating with engaging the work of Marxist educators.

PJ: Departing from the Frankfurt School of Social Science, contemporary critical theories of technologies have developed into various directions (including, but not limited to, the elusive fields of postmodernism). Some of these theories ended up quite far from their Marxist roots; nowadays, they seem stuck at the place which you left more than a decade ago. Can you elaborate your return to Marxism as a theoretical base for reinvention of critical education in the context of information and communication technologies?

PM: Well, I began with an autonomous Marxist focus - the self-activity of the working class - and I was initially drawn to the work of important thinkers such as Antonio Negri, Michael Hardt, Raniero Panzieri, Mario Tronti, 
Sergio Bologna, Mariorosa Dalla Costa, Francois Berardi, and others, although I didn't explicitly deal with their work in my writings on education. I moved towards an appreciation of more classical Marxist critique, the work of Mas'ud Zavarzadeh, Teresa Ebert, for instance, then I became interested in the Marxist humanism of Peter Hudis, Kevin Anderson and Raya Dunayevskaya, and of course the work of British educators Paula Allman, Mike Cole, Dave Hill and Glenn Rikowski. So I began with an interest in what has been described as a new era of capitalist development that was variously described under the epithets 'post-industrialism', 'post-Fordism' or 'postmodern capitalism'.

Here the emphasis was on information age capitalism via information technologies - computers and telecommunications - used by capital to create capital mobility across national boundaries and eventually the national security state of widespread societal surveillance. Even though my many visits to Latin America convinced me that we have not in any way left the smokestack era of factory production, I became interested in the various ways that capital has penetrated the entire society by means of technological and political instruments in order to generate a higher level of productivity and in order to monitor and reconstitute its response to the self-organization of the working class through these new technologies. Of course, innovations in the context of knowledge production and communication in the new information society do not merely serve as instruments of capitalist domination, but can be employed in creating alternative and oppositional movements in the larger project of transforming capitalist society into a socialist alternative.

PJ: There has been a lot of water under the bridge since Marx developed his theories. Please address some contemporary challenges to his dialectical thought.

PM: I am critical of autonomous Marxists such as Hardt and Negri who, in books such as Empire (2001), argue that the multitude, who have amassed the necessary 'general intellect', are now in place as a web of resistance to capitalism - and they have done so simply by refusing to reproduce capitalism, without any unifying philosophy of praxis. Marxist-humanist theorist Kevin Anderson correctly sees this as a rejection of transcendence in favor of immanence (i.e. a rejection of Hegel). He writes:

This gaping flaw in Empire is rooted in the type of philosophical outlook they have embraced, one that radically rejects all forms of what they term transcendence in favor of staying on the plane of immanence, i.e., taking elements within the given social reality as one's point of departure...

But we do not have to choose between such one-sided alternatives. Consider Hegel's standpoint, as summed up by Theodor Adorno of the Frankfurt School: 
'To insist on the choice between immanence and transcendence is to revert to the traditional logic criticized in Hegel's polemic against Kant' (Adorno, Prisms, p. 31). In fact, Hardt and Negri regularly attack Hegel and the Enlightenment philosophers as conservative and authoritarian, while extolling preEnlightenment republican traditions rooted in Machiavelli and Spinoza. What they thereby cut themselves off from is the dialectical notion that a liberated future can emerge from within the present, if the various forces and tendencies that oppose the system can link up in turn with a theory of liberation that sketches out philosophically that emancipatory future for which they yearn.

Marx certainly overcame the pre-Hegelian split between immanence and transcendence. The working class did not exist before capitalism and was a product of the new capitalist order, and was therefore immanent or internal to capitalism. At the same time, however, the alienated and exploited working class fought against capital, not only for a bigger piece of the pie, but also engaged in a struggle to overcome capitalism itself, and was in this sense a force for transcendence (the future in the present). (Anderson, 2010: 11-12)

Here we see, as with Habermas, a rejection of all forms of radical transcendence and a refusal to conceptualize dialectically an alternative to capitalism. As Anderson notes, doing so inspires a fear of utopianism, or worse, authoritarianism and colonial hubris. For Habermas, Hardt, Negri and Holloway, there appears to be a fear of the Promethean side of Marx's humanism that, Anderson notes, points towards transcendence of the given. Thus, in the case of Habermas, we return to a reformist liberalism, and Hardt and Negri are moving towards a poststructuralist radicalism.

The solution, as Anderson proposes, is to 'stare negativity in the face' (to cite Hegel), and work within a variegated dialectical that takes into consideration race and ethnicity, gender, sexuality and youth. We cannot just refuse to take state power, as John Holloway and others recommend, since the state with its pernicious logic of domination will continue to exist until we have created a new social order, one that consists of freely associated labor on a world scale.

PJ: Marx's attitudes towards technology are often generally outlined by the famous quote from The Poverty of Philosophy - Answer to the Philosophy of Poverty by M. Proudhon: "The windmill gives you society with the feudal lord; the steam mill, society with the industrial capitalist" (Marx, 1955). In order to reinvent his critique in the network society, therefore, it is reasonable to ask: What do information and communication technologies give us regarding the contemporary relationship between capital and labor?

PM: Capital's political command over labor-power is the central antagonism facing capitalist societies worldwide. I agree with some of the autonomist Marxists that capitalism does use technological renovation as a weapon 
to defeat the working class and that this certainly helps to explain capital's tendency to expand the proportion of dead or "constant" capital as against living or "variable" capital involved in the production process. The proliferation of information and communication technologies has to be understood in the context of the struggle between capital and labor. But capital still remains dependent on collective labor as the source of surplus value. So capitalism has to constantly reorganize itself through a re-compozition of the state - today we find this as an inexorable push towards social fascism - and to recompose the workforce - whether under the umbrella of lifelong learning strategies, telecommunications, flexible labor policies, a growth of the service economy, and the criminalization of those who cannot complete in the workforce and then privatizing the prisons and turning them into sites of surplus value production.

Clearly, the world could be headed towards the type of informatics dystopia dominated by the guardians of the security state, as Assange notes. But that of course does not rule out entirely the use of information and communication technology to create sites of resistance and transformation. As technological innovation becomes a permanent feature of capitalist relations of production within the new network society, production becomes intensified around cultivating new consumers by producing "transhumans" with new needs, as countries in the global periphery are turned into a giant factory and others are turned into giant fortresses of consumption. Network society is trapped within structured inequalities and there is strong evidence that information and communication technology is further entrenching such structured inequality rather than abating it.

As long as capital governs technology (and not the other way around) in its attempts to commodify every niche of the lifeworld, technology will perilously serve as an instrument of converting all aspects of nature into commodity-form, and rupturing and turning into raw materials whatever planetary metabolism remains life-sustaining. The technoscientific agenda of capital is ominous and has resulted in epistemicide and the destruction of many indigenous approaches to the relationship between humans and planetary ecosystems. While there are efforts to create counter knowledge that take into account self-reflexivity and recursive interactions between nature and technology, how can they be de-linked from capitalist appropriation of social knowledge in all of its forms? Marx talked about the possibility of machines becoming organs of participation in nature. But capital will always hijack this process which is why we need to create a social universe that is not ruled by the sovereignty of labor's value form.

The violently wielded dominative power of machine technology cannot be contested through the creation of a non-capitalist commonwealth based on 
democratic principles. We can't turn our intellectual activity into intellectual capital so that it becomes an appropriated commodity form by universities or other corporatized entities. The same with online teaching in virtual learning factories where what cannot be digitalized loses value and significance.

\section{Karl Marx and Liberation Theology}

PJ: What are the main points of convergence between liberation theology and the works of Karl Marx?

PM: In his 1980 masterwork, Marx against the Marxists: The Christian Humanism of Karl Marx, José Porfirio Miranda, who was educated at the Pontifical Biblical Institute in Rome and who had previously studied sociology in the Frankfurt School, argues that Marx was a Christian humanist who understood the extortionate and unscrupulous characteristics of Christianity and how it was turned into a fraudulent and profiteering caricature of the Gospels when Christianity became the God of empire. Post-Vatican era liberation theologians such as Miranda have recognised and attempted to transcend the role of the Church as reproductive of structural sin (the social relations of capitalist exploitation) to the form of liberating praxis, creating the conditions of possibility to find justice in history. According to Boff (1982: 96), in the first post-Vatican II era (1965-70) there arose an extraordinary effort on the part of the clergy to divest itself of the signs of power, to enter more deeply among the people, living their ministry not as someone above and beyond the faithful (priest), but as a principle of encouragement, unity, and service (ordained minister).

In the second post-Vatican age (1970-80), campesinos and lay people began to organize themselves into base communities, "where there is an experience of a true ecclesiogenesis" (Boff, 1982: 96).

Boff (1982: 98) contends that the poor serve as the sacrament of Christ, who, "as eschatological judge $[. .$.$] judges each one according to the love that$ either liberates from poverty or rejects its plea". The idea of God as eschatological judge permeates Miranda's magisterial works of liberation theology. Rather than antiseptically cleaving liberation theology from Marx's historicaldialectics, as one often discovers in the congeries of opinions of liberation theologians, Miranda sees their intimate connection as a leavening of social justice. Neil Hinnem (2013) is correct is locating the convergence between Miranda's understanding of the biblical perspective on history and Marx's historical-dialectics in Miranda's articulation of orthopraxis and his concept of historical events, the most important event for Miranda being the intervention of Yahweh into human history. As Hinnem (2013) writes: 
History is not an evolutionary process: rather, it is punctuated by revolutionary events. For Miranda, these events are the interventions of God in history for the sake of human justice, culminating in the Christ event, ushering all believers in the Kingdom of God. This event leads, consequently, to the Kingdom's underlying hope, its absolute command, that justice be achieved. "In the historical event of Jesus Christ", writes Miranda, "the messianic kingdom has arrived."

For Miranda, the Bible is a subversive document that preached communism long before the time of Karl Marx. Miranda sees much in common between history as liberation from alienation as described by Marx, and the eschaton, or the divine plan for the realization of the Kingdom of God.

PJ: An important aspect of Christian mystic - and the one you earlier identified as one of the main intersections between Christianity and Marxism - is the eschatological aspect of history. For Christians, this eschaton is the (arrival of) the Kingdom of God; for Marx and Engels, it is utopian socialism predicted as early as in the Communist Manifesto (Marx and Engels, 1848). Can you elaborate upon this eschaton a little deeper? What, foryou, is the Kingdom of God?

PM: We have to honor the victims, speak to their lives of suffering in their theological reality. As Sobrino notes, the crucified peoples of this earth must not be remembered as some historical add-ons to our Sunday sermons but as those who were victims of the anti-Kingdom. After all, the anti-Kingdom is the Kingdom of Capital, of Wall Street and the world of value production (i.e. monetized wealth), of profit, of the exploitation and alienation of human labor, of private ownership of the means of production, of the market mechanism that forces capitalists (regardless of whether or not they are good people) to exploit workers, of the emergent transnational capital consolidated in a global capitalist historic bloc and the pillage zones of America Latina, and of the deregulated, informalized, and de-unionized capital-labor relation and the worldwide subordination of labor.

But here I need to emphasize something Sobrino (2001) has discussed at length in his many important writings. While we focus on the divine in Christ, we have forgotten the Kingdom of God of which Christ speaks. So when we identify as Catholics, why have we forgotten the primacy of creating the Kingdom of God and bringing it forth as Christ exhorted us to do? In my view, it is because our entire system operates as the anti-Kingdom. Christianity itself is undergirded by the imperatives of the anti-Kingdom in that it has attached itself to the imperatives of capitalism. To create the Kingdom of God means seeking the creation of a social universe outside of value production, or the production of profit for the rich. Creating the Kingdom of God means liberating the poor and this means ending the brutal war against the poor unleashed 
by the deregulation of the market. It means challenging the anti-Kingdom that stands against immigrants seeking a better life, against migrant workers, against refugees, and the intergenerationally reproduced barrios of planet slum. We focus instead on eternal life, on gnostic mysteries, and distance ourselves from the Kingdom of God with reality TV and the hundreds of TV channels we have at our disposal. We confuse the drive to increase material wealth with the drive to produce value, or create endless profits that can be expanded indefinitely.

In our forays into the hinterlands of mysticism, we cannot forget that the Kingdom of God is, in Sobrino's terms, a "type of historical-social-collective reality" (2001: 334) and not, as the old union song has it, a "pie in the sky when you die." The Kingdom of God is not some metaphor for an unearthly paradise, some ecclesiastical makeover of the earth in terms of the divine Christ or such that the holy and apostolic church becomes the prime sign or marker of the Kingdom. Clearly, for me, the Kingdom of God is not some place where wellheeled and aristocratic-looking souls lounge about in togas and golden wreaths. For me, the Kingdom of God is more likely found on the picket lines, in the temple cleared of the moneylenders, in a world where the rich no longer dominate, a world where death squads do not murder peasants with impunity, and where poor tenants do not confront racist landlords and developers do not build themselves towers in glorious homage to their wealth and power while others are forced to sleep under bridges.

PJ: Can you link the Christian eschaton described as the Kingdom of God, to Marx's prophecy of the future socialist society?

PM: I do see socialism as fitting in with the Kingdom of God announced by Jesus. Socialists in the past have sometimes made such a connection. Take the case of Helen Macfarlane. In 1850, Scottish governess, Helen MacFarlane, wrote polemical treatises supporting the Chartist movement. She was the first person to translate Hegel's philosophical writings into English and the first person to translate The Communist Manifesto into English. The Chartists were the first working-class movement to fight the British establishment in order to secure rights for the working class. For a time, MacFarlane supported Chartist leader Julian Harney in rebuilding the movement from a socialist and international perspective and refused to moderate the movement to win over the radical liberals. She allied herself with Marx and Engels and took on literary giants such a Thomas Carlyle and Charles Dickens. She interpreted Hegel as a humanist pantheist and she defined pantheism in humanistic terms. Her work reflects the Hegelian pantheism of David Strauss and her engagement with Marx and Engels helped her to radicalize Strauss's critical Hegelianism. For Hegel, the importance of the gospels was their symbolic content. For 
David Strauss, what was important about the gospels was their historicity - as myths that contained the Messianic desires of the early Christian communities (Black, 2014: xvii).

Feuerbach believed that theological knowledge was subjective and that the final criterion for the truth was to be found in the senses. Here the ego remains passive and determined by objective reality. For Marx, truth was found through historical praxis, through the negation of the negation. What is interesting about Macfarlane was her ability to merge the ideas of socialism, left Hegelianism, and Marxism with the teachings of Jesus and in doing so spiritualize the struggle for social justice. In 1850 she wrote:

We Socialist-democrats are the soldiers of a holy cause; we are the exponents of a sublime idea; we are the apostles of the sacred religion of universal humanity. We have sworn by the God who "made of one blood all nations of the Earth", that we will not pause till we have finished the great work - begun by the Nazarean - of man's redemption from the social miseries which destroy body and soul. (Macfarlane in Black, 2014: 22)

PJ: If the Kingdom of God is a "type of historical-social-collective reality" (Sobrino, 2001: 334), why should we not just stick to Marx and Engels' utopian socialism? Why, in this context, do we need a God?

PM: As a species on the verge of extinction, we have an ongoing obligation today to commit ourselves to build a network amongst the working class, the peasantry, and the urban cognitariat and precariat in order to break down the immutable hierarchies of power and privilege concomitant with the workings of capitalist society. In our struggle to achieve this, God will be revealed. As Miranda writes: "Only in a world of justice will God be" (1977: 45). The revolution therefore depends not on the man himself or the woman herself or on the collectivity (which would be merely expanded egoism), but on the Other. Providing for each according to his or her needs presupposes caring for people simply because they exist and are God's children. The social relations of capitalist exploitation can force us to yield but they cannot oblige us to obey. God is the moral imperative itself, the imperative to struggle against injustice and innocent suffering. God's presence in history, the true revelatory intervention of the God of the Bible in human history, occurs when we take up the struggle for social justice.

It is interesting to note that Marx and Engels entered an organization in 1872 that was founded by Wilhelm Weitling, the founder of German communism. Weitling's organization was based on a communism grounded entirely in the gospel, as can be seen in his 1845 book, The Gospel of a Poor Sinner (Miranda, 1980). Marx was a great admirer of the Peasants' War organized and directed by Thomas Munzer in the 16th century. This was, in effect, the first anti-capitalist 
revolution. Munzer argued that the Kingdom of God is a condition of society without class differences, without private property, and without state powers opposed to the members of society.

PJ: Your work is a masterpiece of dialectics... Where issues pertaining to ontology and epistemology pour into issues pertaining to politics and emancipation, there still is - even if only historically constructed - some sort of "division of work" between the different approaches and disciplines. What is the main strength of Marxism in the context of liberation theology?

PM: I return to the basic issues of the violence of capitalism, colonization, genocide, and the underlying epistemicide, which can be best understood as the destruction of epistemologies, ways of knowing, and ecologies of the mind of indigenous peoples throughout the world. Now for some proponents of liberation theology, communism as Marx envisioned is normative in the message of Jesus. And I have faith that the Kingdom of God will overcome the world of suffering precisely because I have faith in the people, the workers, the masses to defeat capital and bring about a more loving and human system for providing for the material needs of humanity. Terry Eagleton writes:

I have argued already that reason alone can face down a barbarous irrationalism, but that to do so it must draw upon forces and sources of faith which run deeper than itself, and which can therefore bear and unsettling resemblance to the very irrationalism one is seeking to repel. (Eagleton, 2009: 161)

It is worth remembering, as Eagleton notes, "The Christian way of indicating that faith is not in the end a question of choice is the notion of grace. Like the world itself from a Christian viewpoint, faith is a gift" (2009: 138). Of course, this does not mean we cease examining our faith with evidence from the phenomenal world. Eagleton sees the great struggle today as one in which culture is pitted against civilization. He notes that "culture ... is too much a matter of affirming what you are or have been, rather than what you might become" (2009: 165). And as for religion? Eagleton writes:

What we know as Christendom saw itself as a unity of culture and civilization. If religion has proved far and away the most powerful, tenacious, universal symbolic form humanity has yet to come up with, it is partly on this account. What other symbolic form has managed to forge such direct links between the most absolute and universal of truths and the everyday practices of countless millions of men and women? What other way of life has brought the most rarefied of ideas and the most palpable of human realities into such intimate relationship? Religious faith has established a hotline from personal interiority to transcendent authority - an achievement upon which the advocates of culture can only gaze with envy. Yet religion is as powerless as culture 
to emancipate the dispossessed. For the most part, it has not the slightest interest in doing so. (2009: 165-166)

But what of Marxism's potential in reconciling culture and civilization? Eagleton responds as follows:

If Marxism holds out a promise of reconciling culture and civilization, it is among other things because its founder was both a Romantic humanist and an heir of Enlightenment rationalism. Marxism is about culture and civilization together - sensuous particularity and universality, worker and citizen of the world, local allegiances and international solidarity, the free selfrealization of flesh-and-blood individuals and a global cooperative commonwealth of them. But Marxism has suffered in our time a staggering political rebuff; and one of the places to which those radical impulses have migrated is - of all things - theology. It is in some sectors of theology nowadays that one can find some of the most informed and animated discussions of Deleuze and Badiou, Foucault and feminism, Marx and Heidegger. (2009: 167)

What I find most important in Marxism is its explanation of how capitalism works to necessarily exploit workers and the environment, provoking workers to rise up and replace capitalism with socialism and eventually the state will wither under communism. Both Jesus and Marx have an eschatological view of history and, as Michael Rivage-Seul (2008) notes, Jesus challenges us to reject the worship of a divinized violence that feeds the "satanic military industrial complex" and practice a non-violent form of resistance against differentiating wealth.

PJ: In Pedagogy of Insurrection, you write:

Critical pedagogy is the lucubration of a whole philosophy of praxis that predates Marx and can be found in biblical texts. If we wish to break from alienated labor, then we must break completely with the logic of capitalist accumulation and profit, and this is something to which Marx and Jesus would agree. (McLaren, 2015: 54-55)

If Marx and Jesus would agree with the break from alienated labor, why does contemporary revolutionary pedagogy need an additional layer of rituals and beliefs 
offered by Christianity? More generally, what are the unique emancipatory and educational potentials of Christianity, which cannot be found in traditional nonreligious Marxism?

PM: My early work was on the topic of ritual - Schooling as a Ritual Performance: Towards a Political Economy of Educational Symbols and Gestures (McLaren, 1999). Here I followed the work of contemporary symbolic anthropologists - especially Victor Turner - in examining rituals as embodied metaphors and in relation to the construction of liminality. I applied these theories in a critical ethnography I undertook at a Catholic middle school in the Azorean community of Toronto. I was able to discern rituals of instruction, of accommodation, and how an anti-structure of resistance was possible under certain conditions. I also identified micro and macro rituals in school settings and how they can be both emancipatory and contribute to the reproduction of hierarchies of power and privilege. I articulated a theory of the teacher as a liminal servant and how the construction of liminality in the classroom can be the seedbed of true creativity, but at the same time a flashpoint for violence. Much of the important work in applied theater, in drama, and performance studies builds on conceptions of ritual. This can be seen in the writings of my late thesis advisor and mentor, Richard Courtney, and is paramount in the work of Augusto Boal - especially in his magisterial volume, Theater of the Oppressed (2008), which was very much influenced by the work of his fellow Brazilian, Paulo Freire.

I was fortunate to participate in a public dialogue with Freire and Boal at the Rose Theater in Omaha, Nebraska, in the early 1990s. It was the first time Freire and Boal had appeared together in such a venue and I was honored to have been a part of this historic event. Symbols have a fecundity that become animated in rituals. They are brought to life, and live inside of us, through play, through rituals, and their elaboration can be seen in the evolution of drama and thought. Symbols are enacted and work synergistically with other symbols; I have termed this process "enfleshment." Here religious and secular symbols can, under specific historical and existential circumstances, hemorrhage into each other and can work in very liberating and also in very dangerous ways. Just think of Francoist Spain and the rituals that linked Catholic symbols to fascism.

According to Miranda (1980), Jesus was the first human being in history to denounce money as the object of idolatry, which centuries later Marx referred to variously as the Biblical idols of Baal, Mammon, and Moloch. In fact, when discussing the commodity form of production, he used these terms as much as he did the word "fetish." When Saint Paul talks about the "lust which is idolatry," he is referring to money. Book Three of Capital (Marx, 1981) makes clear 
that the capitalist mode of production is not the origin of class violence in capitalist society. As Miranda (1980) notes, the class division is created outside the sphere of production, when money becomes god, and it was this god that created the conditions of possibility for the capitalist mode of production. Money as exchange value stands outside production and circulation and yet dominates both. Money represents the autonomous existence of value as the concretization of human labor. It is when money no longer represents commodities, but when commodities represent money, that money becomes a god. Money is the god of all people living under the commodity mode of production and money had already become a god during the time of Jesus. In other words, the accumulation of capital is not enough to automatically create the mode of production we know today as capitalism, because it takes a certain type of historically produced civilization. The transformation of money into capital requires a certain kind of historical circumstance. Today, capitalism still functions as the institutionalization of the worship of Mammon.

Marx does a brilliant job of explaining how money was transformed into a god ruling human beings. Marx reveals how money is both the object and fountainhead of greed, of auri sacra fames, the product of a historically conditioned environment. According to Miranda (1980), Marx perceived the switching of the subject into an object and the transformation of the ends into the means as the centerpiece of the making of a false religion. Marx then applied this "conversion" to economics, to the production of value. Capital finds a way to exchange itself for a commodity that produces more value than the commodity itself - labor power. Capital moves into production through an exchange with labor power, via wage labor, which brings about the separation of the direct producers from the owners of the means of production. Interest-bearing capital is a fetish, a self-expanding value, and it expands its value independently of reproduction, which is a reversal of the relationship between persons and things - all pointing to Marx's anathematization of the worship of money as god. Miranda (2004) points out that at the very central point of his analysis of capital, at the very point where he uncovers the birth of money as a commodity, Marx cites two entire versus from the Apocalypse (Bible, 17:13; 13:17). Marx offers a scientific elaboration of Christ's teaching about the god Mammon.

PJ: The understanding of money as a god which rules human beings fascinates me. Can we say that it is one of the central points of connection between Christianity and Marxism?

PM: Jesus talked so much about economic sin that it is unfathomable why this is not a central part of the teachings of Christianity. The Lucan part of the Bible explicitly teaches communism (Acts 4:32; 4:34; 2:44; Luke 14:33). Miranda argues that the origin of the communist idea in the history of the 
West is not to be found in Plato or Marx but rather in the New Testament. The Bible clearly condemns acquired wealth and established wealth and also the means by which this wealth came to be - including various kinds of profit, such as interest on loans, and the expropriation of the produce of the workers' labor by agricultural entrepreneurs (James 5:1-6). Jesus is not against generalized wealth per se, such as the wealth of a people, but against relative or differentiating wealth. Someone cannot be rich while another remains poor. Mark 10:25 and Luke 6:20, 6:24, 16:19-31, 1:53 are interpreted by Miranda as arguing that there is no legitimately moral means of acquiring differentiating wealth and that Jesus maintains (Luke 16:29, 16:31) that the same condemnation of wealth can be found in the Old Testament.

Actually, three types of profit are attacked in the scriptures. The Bible itemizes its reproof of profit-taking as occurring through commerce (Ecclus 27:1-2), loans on interest (Exodus 22:24; Leviticus 25:36, 25:37; Deuteronomy 23:19; Ezekiel 18:8, 18:13, 18:17, 22:12; Psalms 15:5; Proverbs 28:8.), and productive activity or the process of production (James 5:1-6). There is something about the process itself of being able to grow rich that is wicked and unjust (Isaiah 53:9). The acquisition of wealth itself is possible only by exploiting the poor (Job 20:19; Psalm 37). Micha 2-1-2, as well as Isaiah 5:8, focus on how the rich keep acquiring property. Miranda $(1974,1980)$ makes a convincing case that the Bible condemns the exploitation suffered by the poor at the hands of the rich and creates an identity between the rich and the unjust (Isaiah 53:9). Jesus' teachings that enabled the first Christians to base their community on communism can be found in Mark 10:25, Luke 6:20, 24, Matthew 6:24, and Luke 16:19-31.

In fact, Miranda (1980) makes the claim that Jesus was a communist, which can be seen in John 12:6, 13:29, and Luke 8:1-3. Did not Jesus make the renunciation of property a condition for entering into the Kingdom of God? How can God make it possible for a rich person to enter the Kingdom of God? The answer is clearly provided by the Bible. According to Miranda this answer is: By ceasing to be rich (Mark 10:21, 25, 27) and giving away one's wealth to the poor. The scriptural exegesis undertaken by Miranda is, to me, thoroughly persuasive. As a revolutionary Marxist, I am certainly drawn to a number of Miranda's works, Marx and the Bible (1974) and Marx against the Marxists (1980).

PJ: Poverty is a central point of departure for Jesus, Marx, and Paulo Freire. Yet, the answers seem to collide. For Jesus, the poor will inherit the Kingdom of God; for Marx and Freire, the poor should take matters in own hands here and now...

PM: Jesus did not sacralize poverty or preach resignation to it because there will be some extra-terrestrial compensation for it in the afterlife. That would be a glib and cynical assessment, and it erases the prophetic nature of such a pronouncement. To say the poor are blessed is not an involuntary justification 
of the relations and structures of exploitation. The poor are blessed because the coming of the Kingdom in the fullness of history will put an end - in the concrete sociological sense - to their poverty and suffering. Poverty is a form of structural sin that is incompatible with the Kingdom of God. I am not trying to reduce the Gospel to a manual for attaining political consciousness but maintaining that the Gospel has an inherent political dimension. As Gustavo Gutierrez notes,

This conscienticizing of the preaching of the Gospel, which rejects any aseptic presentation of the message, should lead to a profound revision of the pastoral activity of the Church ... the oppressed themselves should be the agents of their own pastoral activity. (1988: 154-155)

PJ: Socialist society may indeed be very close to the Kingdom of God, yet Marxist and Christian methods for achieving the eschaton seem quite different. In the Communist Manifesto, Marx and Engels write "Workers of the World, Unite. You have nothing to lose but your chains!"; 1 Matthew 5:5 says "Blessed are the meek: for they shall inherit the earth". What about these differences in views to human agency, Peter? What is their relationship to labour?

PM: For Marx, human beings clearly are subjects, subjects of history. The subject of history is related to Marx's concept of living labour, of labour-power, the potential for labouring, the capacity for labour, its possibility and potency. It is living labour that is present in time and throughout human history as possibility, whereas objectified labour serves the means and instruments of production and has no role in liberation from oppression. Marx describes how the capitalist production process makes relationships between persons seem as relationships between things. For Marx, capital grounds all social mediation as a form of value, and that the substance of labour itself must be interrogated because doing so brings us closer to understanding the nature of capital's social universe out of which our subjectivities are created. Because the logic of capitalist work has invaded all forms of human sociability, society can be considered to be a totality of different types of labour. What is important here is to examine the particular forms that labour takes within capitalism. In other words, we need to examine value as a social relation, not as some kind of accounting device to measure rates of exploitation or domination. Consequently, labour should not be taken simply as a 'given' category, but interrogated as an object of critique, and examined as an abstract social structure.

1 We are well aware that this phrase is a popularisation, which does not exist in the Communist Manifesto - yet, it does adequately describe the dichotomy between Marxist and Christian views to human agency. 
For Marx, the commodity is highly unstable and non-identical. Its concrete particularity (use-value) is subsumed by its existence as value-in-motion or by what we have come to know as "capital". Value is always in motion because of the increase in capital's productivity that is required to maintain expansion. The dual aspect of labour within the commodity (use-value and exchangevalue) enables one single commodity - money - to act as the value measure of the commodity. Thus, the commodity must not be considered a thing, but a social relationship. You could describe the "soul" of capitalist production as the extraction from living labour of all the unpaid hours of labour that amounts to surplus-value or profit. Marx's analysis of the fetishism of the commodity form bears a strong kinship to the New Testament's references to "false gods". But, as Lebacqz (1986: 107) argues,

[...] in spite of its affinity with Marx's analytic methods and social goals, the view of justice provided in liberation theology is not simply a new version of "to each according to need". Justice is not a simple formula for distribution. Justice would not be accomplished merely by offering programs that meet basic needs of the poor. Justice requires the kind of liberating activity that characterizes God's behaviour toward the poor and oppressed [...] there is no separation of "love" and "justice". God's justice is God's love or compassion on those who suffer. God's love is God's justice or liberation of the oppressed.

Marx was a humanist, and this is clear in both his private letters but also his published works, but whether he was a Christian humanist as Miranda maintains remains very much an open question.

PJ: Marxism aims at social change through collective action, while Christianity is much more focused to individual development. Obviously, this is not an either-or relationship - as Paulo Freire (1972) would say, collective acts of emancipation are necessarily preconfigured by individual consciousness. What is your take on this tension between (Christian) individualism and (Marxist) collectivism?

PM: The emphasis in Christianity on otherworldliness (don't worry if the bad people are not caught and punished, they will be punished in the afterlife) has often been used as a moral justification for the consecration of deception, either by encouraging passive resistance to exploitation or labelling the unmasking of deeper truths about empire as too subversive, too "anti-American" a posture that tends to make people unworldly or uncaring about others. Yet, as De La Torre (2015: 162) warns: "History demonstrates the futility of simply denouncing unjust social structures for those whom the structures privilege will 
never willingly abdicate what they consider to be their birthright". The mere moral exercise of political power through passive protest is not a convincing answer since the idea of the moral exercise of political power ignores what political power is: the state is (not as an abuse but by definition) "the monopoly of legitimate violence". While parts of the state machine may be "very peaceful", the threat of violence, backed up by armed forces, is always presupposed. And the practice of politics, whether in office or in opposition, is always war (mainly class war) carried on by other means. Non-violent politics is a contradiction in terms. (Collier, 2001: 104).

So instead of fighting to change the structures of oppression, people either focus on remaking themselves as individuals into better persons (there are plenty of self-help books out there) or they become indelibly indifferent to politics or political change.

Marxism rejects this Cartesian sense of "liberty of indifference" (changing oneself rather than changing the world) and "the preference for autoplastic solutions which underlies it" (Collier, 2001: 100). While one is necessarily changed by changing the world (what we call praxis), that does not mean that all attempts to change ourselves are unnecessary or futile - since resistance to oppression requires us to adapt to changing circumstances, and adaptation requires all kinds of strategies of self-change. After all, in his Theses on Feuerbach Marx (1976) writes that: "The coincidence of the changing of circumstances and of human activity or self-changing can be conceived and rationally understood only as revolutionary practice". If we act as if the eschaton has already arrived, and we are preparing for the reign of God, then is this not a necessarily a quixotic predicament, but a form of pre-figurative politics.

Letting the reign of God be prefigured in our present lives, whether we image that reign to be a communist society or the Kingdom of God, there is no guarantee that our good actions will bring about its completion - but if we post-date our best ethics to the future communist society or Kingdom of God, then our good actions will, at least, have intrinsic values in themselves. Our organisation and actions should prefigure the socialist revolution or the coming of the Kingdom of God. While it may be true that means do not always resemble ends, Collier argues that "[s]o long as human authority exists, it should as far as possible be organized so that the greatest power serves the least powerful with all its might" which in its contemporary form is called "the dictatorship of the proletariat" (Collier, 2001: 122).

PJ: Both the Bible and the works of Marx can be read in many different ways Isurely don't need to remind you of historical a trocities which resulted from certain readings of both doctrines... While it is tempting to seek concordances between 
seminal Christian and Marxist texts, I would like to ask a more fundamental philosophical question: How commensurable are the philosophies of Marxism and Christianity?

PM: Denys Turner (1983) has contributed some important insights with respect to the compatibility of Marxism and Christianity that are worth repeating here. Both Marxism and Christianity are compatible with a materialist theory of history yet hold to a denial of ontological materialism. We are talking here not about a formal or Cartesian logical consistency between Marxism and Christianity but a dialectical consistency.

It is true that there exists no coherent synthesis between Christian doctrines and Marxist theory, but that all the more makes it imperative that we abandon the rhetorical homologies often found in liberation theology - "the anawim [the poor and the oppressed referred to in the Old Testament] become the proletariat, liberation becomes redemption politicised, alienation is original sin [....] the priesthood metamorphosized into Lenin's revolutionary leadership" (Turner, 1983: 211-212). These homologies are useful, politically, to inspire the struggle of impoverished communities against well-armed death squads, but they must not be viewed as strict equivalences, since this could lead to uncritical forms of triumphalism.

PJ:I'm glad we're on the same page!

PM: While Marxism and Christianity seem to be incommensurable languages, both are constitutively necessary to explain reality and to understand what forces and relations shape the human condition. Both are part of the praxis of history and can be viewed as historically conditioned action systems, defined by their relationship to historical contingencies. As Turner (1983) reminds us, Marxism requires abolishing the conditions which require it - capitalist exploitation. Similarly, according to Turner, Christianity will realize itself only at the cost of its abolition as Christianity since its realization will become a fully human reality rather than a sacred reality - a fully socialized humanity and a fully humanized society consisting of love.

However, as Turner (1983) cogently argues, because God is non-identical with the contingencies of any particular form of history, our full humanity can only be known through aspirations for liberation which cannot be realized in practice. We need to secure the conditions of that absence of a presence which we can only symbolize and understand heuristically. We cannot love, we cannot be free, we cannot know God, we cannot know how we can live without oppression, because the Kingdom of God has not been realized; we can only work as Christians and Marxists to secure the conditions of the possibility of loving and living freely. Under capitalism, under the prevailing institutional structures of exploitation, love and freedom can only ever be ideological. We can 
only anticipate love in its absence, we can never truly see love fulfilled under the conditions of capitalism. In the conditions of bourgeois society, any further claims about love are only ideological. In a world of dehumanised, alienated social relationships, we can only symbolize love through its absence, and so we can say that love, and generosity, and goodness, and Christ are present in this world but present only in the form of their absence.

PJ: Speaking of the conditions of freedom, and of anticipation, we enter directly into the area of morality. Christian morality is quite theoretically robust, yet, as Rosen (200o: 21) says, "the question whether Marx's theory has a moral or ethical dimension is one of the most controversial of all issues of Marx interpretation". What is your take on that question?

PM: Marxism is, in this sense, morality itself, because, as Turner (1983: 215) argues: "it consists in the knowledge of what to do given the 'facts"'. Marxism is the fundamental science of capitalism and reveals morality in capitalist society to be ideologically bourgeois. Marxism is thus all that morality can be - it represents the outer limits of morality - given today's existing conditions of capitalist exploitation and oppression. Marxism is "the theory and the practice of realizing the conditions of the possibility of morality" (Turner, 1983: 215), while at the same time, it is not possible for Christianity to be regarded as coterminous with Marxism even when Marxism "is demonstrably the scientifically warranted response to the conditions of any particular historical epoch" (Turner, 1983: 213). And this is true "even if it follows from the fact that Christianity can know itself and the nature of its praxis only through the Marxist criticism of it" (Turner, 1983: 213). So while Marxism argues about "the impossibility of moral knowledge in capitalist conditions", it exists as a revolutionary form of praxis in that it points out how it is impossible for capitalism to conform to its own truth in practice "since conformity is structurally impossible for capitalism" (Turner, 1983: 213).

Christianity attempts to "symbolize the depths of what is to be human in the form of a sacredness, in the form of the refusal to admit what is most fully human could be compatible with the conditions of alienation and exploitation which historically obtain" (Turner, 1983: 213). Thus, Christianity recognizes love as the point of its praxis but it is a love which, under capitalism, can only be anticipated. Turner makes a prescient point when he argues that the absence of morality in Marxism is not in any sense a "mere a moralism" because it reveals that it is capitalism, not Marxism, which is a moralistic. In other words, 
Marxism reveals the "platitudinous imperatives, so forthcoming from Christians, to 'love' within conditions of gross and systematic exploitation" (Turner, 1983: 216) and Christianity's "transhistorical pretentiousness" in believing that Christ's presence in history is not historically contingent, that is, not dependent on any particular historical or economic conditions.

Adopting a transcendent morality among Christians is what Turner rejects as Christian "fidelism" which focuses on the Kingdom of God being "within you". This is not to deny the presence of God, but that such presence is not in the form of some supernatural text which has already been written; rather, "the unwritten text is present in the struggle to write it" (Turner, 1983: 219). This is very much like the popular proverb by Antonio Machado that one makes the road by walking (Caminante, no hay camino, se have camino al andar). Both Marxism and Christianity have the resources within their own traditions for rejecting immorality - for instance, for rejecting meta-moral principles where, for example, communist society is made into a moral absolute or Christianity is presented as an already written moral text to which only Christians or particularly enlightened Christians have access.

According to Turner, Marx rejected theism as false, because it "supposes an opposition between God and man" (Turner, 1983:165) and he criticises atheism "because it accepts the terms which theism lays down and can speak of man only indirectly, that is, via the negation of theism" (Turner, 1983: 165). Marx rejected the theologically and politically conservative Christianity of his day, as well as the radical Christianity that made its appearances throughout his lifetime. Marx claims that questions pertaining to the existence of God arise only among those who fail to understand their own natural human origins. Turner recognised that Marx rejected contemporary immanentist theologies because he viewed them as a partial regression to negative atheism itself. While Marx rejected negative atheism, Turner does not take that to mean Marx was not an atheist.

PJ: I could somehow swallow that Marx was not a (complete) atheist, but it cannot be disputed that he was very anti-clerical. How does liberation theology, with its close relationships to the Church, absorb Marx's negativity towards its own being?

PM: Marx was anti-clerical, and so would any rational person be during the time of Marx who recognised that Jesus was the antithesis of clericalism, a clericalism whose world-denying conciliar prohibitions infected by monarchism and paternalism, disallowed justice for all. It was a temporal power that germinated autocracy and was leavened by obedience to a hierarchy that almost always sided with the imperial and structural intentionality of the state. It was clear to Marx and like-minded others that the ecclesiology that 
developed from the law, especially canon law, gave the papacy unrestricted power over the laity, resulting in a religious hubris of unrelenting fidelity to empire. It had ripped away from early Christianity sanctioned disobedience to imperial law. Now it demanded compliance to the dictatorship of the ruling class and its despotic commands often leading to brutishness, cruelty and unvarnished terror, to prioritizing sacred laws over human welfare and making the Law of Christ coextensive with the Law of Empire and its imperial covenant directed at capital accumulation by dispossession.

In liberation theology, however, there must be a principled intransigence towards authoritarian power rather than a creative adaptation to it, an eccelsiogenesis $^{2}$ that lives in dialectical tension between the pneumatological ${ }^{3}$ and doctrinal aspect of the church and the base of the Church of the Poor. The Church proclaims a Kingdom of God that it can never put into practice, similar to capitalism that installs the very conditions (wage labour, value augmentation, social relations of production) under which wealth and prosperity are available onto to a few. Yet both cannot abandon the teachings they cannot follow.

PJ: Are there any theoretical and/or practical dissonances between Marxism and Christianity in your theory? If there are, how do you go about them?

PM: While some might argue that traditional non-religious Marxism is not as equipped as theological traditions to engage fundamental questions pertaining to the hermeneutics of spirituality, there are numerous Marxist theorists who have written profoundly about issues of the spirit - here, I am thinking of Ernst Bloch, Walter Benjamin, and Erich Fromm, just to name a few. I think Marxism does address issues of the human spirit, but what interests me, in particular, is an engagement with a tradition that deals with a triune god. Of course, liberation theology comes in many forms: Chicano liberation theology; Latinx liberation theology; Native American liberation theology; African American liberation theology. Therefore, I do not want to limit liberation theology to the political theology that comes out of Europe, or to the Latin American liberation theology that is primarily Catholic and pastoral.

I work as a Marxist materialist but I believe there is a world beyond physicalism. That is a world of hope. Hope is conjugated in opposition to injustice and

2 The term 'ecclesiogenesis' is used by liberation theologian Leonardo Boff to describe the new ecclesiological experience within the Basic Christian Communities created in Latin America in which attempts are made by popular constituencies to create authentic Christian communities. Participants see this as creating a new form of church outside of the institutional structures of the traditional Catholic hierarchy (see Boff 1986).

3 In Christianity, the term 'pneumatology' refers to the study of the Holy Spirit. 
gestated in the struggle of humanity against inhumanity. Rubem Alves (cited in Boff, 1987: 124) writes of hope as follows:

Hope is the presentiment that the imagination is more real, and reality less real, than we had thought. It is the sensation that the last word does not belong to the brutality of facts with their oppression and repression. It is the suspicion that reality is far more complex than realism would have us believe, that the frontiers of the possible are not determined by the limits of the present, and that, miraculously and surprisingly, life is readying the creative event that will open the way to freedom and resurrection...

Hope does not deliver us from suffering. But hope, I believe, can deliver us from the fear of suffering. It does this by giving us the courage to believe that we are not fated to live in misery, that light does shine through the cracks of the day-to-day sepulcher in which we find ourselves, in this cold and damp undercroft, in this darkness of inevitability.

PJ:Marx was a scientist, and his worldview is based on dialectical materialism. Liberation theology is religious, and its worldview is based on faith. How do you reconcile these radically different approaches to reality?

PM: Today in our efforts to create a society constructed upon principles of social justice we have approached our projects as scientifically distilled data big data serves both as our compass and our destination. But allegiance to data removes the consensus-generating process that is part of collective reflection and systematic rationality, as Miranda explains so well. Interpersonal dialogue has to be part of the object of study and rational reflection - since relations between people are the basis of the relations between things. We can't forget this. As Miranda (1980: 306) notes, the "communitarian process leading to consensus can evade the arbitrariness or naivete of extrascientific motives only if we, in all frankness, realize that dialogic discussion does exist, that it is moral in character, and that it is thus a matter of conscience". Without this consideration articulated by Miranda, and reflected in Paulo Freire's (1972) Pedagogy of the Oppressed, we will etherise the role that our conscience must play and fall prey to corruption and self-interest.

We can't separate norms and facts, facts and value, for this expunges meaning from history, and both Marx and the teachings of the gospels recognise this. As Miranda (1980: 307) notes, "The eschaton of Marx, which is the same as that of the gospel, is what gives meaning to history". The project of immanentizing the eschaton is one that has historically struck fear in the hearts of conservatives who use the term pejoratively because it refers to attempts to bring about the Kingdom of God in the immanent world. The conservatives equate this 
with socialism, communism, anti-racism and even Nazism. But reading the Gospel from below mandates that such a project is already in the making, with the intervention of Christ into human history. It is rejected by conservatives for fear of the rise of totalitarianism. But at the root of such fear is that panic in the hearts of those who stand to lose their wealth and status should a state of egalitarianism and equality be achieved.

PJ: What is the main message of Marx's work for liberation theology positioned in, against, and beyond contemporary capitalism (cp. Holloway 2016)?

PM: All of us can become blinded by virtue of our own interests, whether we are atheists, agnostics, Christians, Christian communists, or members of other religious faiths. For example, the capitalist does not realize that what is sold in the transaction between the capitalist is labour-power, not labour sold at its exchange value, and so the capitalist is wilfully blinded to the fact that labour-power produces much more than it is worth simply as exchange value (the labourer works much more than it takes to reproduce his or her own necessities for survival) and operates out of a motivated amnesia that the capitalist has been stealing surplus value from his workers. The Christian and the capitalist rarely think deeply about Marx's notion of value, and both adhere to the empiricist expression "price of labour", which hides the fact that the wage system is, in reality, a form of slavery. This, according to Marx, is an epistemological issue as much as a moral issue. As Miranda points out, Marx did not adhere to a materialist dogmatism that limited epistemology to social class. He recognized that the very mechanism of cognition itself is ideological, and that there are moral values embedded in the process of cognition - that within the apologetics and empiricist ideologies of economists there exists hidden interests which he viewed as ideological.

It is worth remembering Miranda's (1980:303) insight: "Empiricism sticks to things. Marx dissolves things into relations between persons because conscience is not troubled by any moral obligation whatsoever when it confronts things". Hence, it is important for both Christians and Marxists to remember that exploitation and oppression can only be overcome by a sincere willingness to know the truth. Yes, truth is always partial, contingent and contextual, but it can be known. Which is why I believe the work of Marx is so essential to Christianity and why liberation theology needs to be continually reinvented for the current times, especially after such brutal efforts by the Reagan administration and Pope John Paul II to silence it, and efforts by right-wing dictatorships throughout Latin America to crush it by murdering priests and exponents of the Church of the Poor in the 1970s and 1980s. Today, especially today, the world needs liberation theology, which, by the way, is not restricted to Christianity or Christians but to all those who seek justice in these exceedingly brutal times. 


\section{Acknowledgement}

This article presents a selection of material published in following articles: McLaren, P. \& Jandrić, P. (2014). Critical revolutionary pedagogy is made by walking - in a world where many worlds coexist. Policy Futures in Education, 12(6), 805-831; McLaren, P. \& Jandrić, P. (2017). From Liberation to Salvation: Revolutionary critical pedagogy meets liberation theology. Policy Futures in Education, 15(5), 620-652; McLaren, P. \& Jandrić, P. (2018). Karl Marx and Liberation Theology: Dialectical materialism and Christian spirituality in, against, and beyond contemporary capitalism. Triple C: Communication, Capitalism \& Critique, 16(2): 598-607; and McLaren, P. \& Jandrić, P. (2015). The critical challenge of networked learning: using information technologies in the service of humanity. In P. Jandrić \& D. Boras (Eds.), Critical Learning in Digital Networks. New York: Springer. Some parts of the text have been previously republished in English language in McLaren, P. \& Jandrić, P. (2017). Peter McLaren's Liberation Theology: Karl Marx meets Jesus Christ. In J.S. Brooks and A. Normore (Eds.), Leading Against the Grain: Lessons for Creating Just and Equitable Schools. New York: Teachers College Press, 39-48; McLaren, P. (2015). Pedagogy of Insurrection: From Resurrection to Revolution. New York: Peter Lang; Jandrić, P. (2017). Learning in the Age of Digital Reason. Rotterdam: Sense. Some parts of the text have been previously republished in other languages in McLaren, P. \& Jandrić, P. (2015). Critical revolutionary pedagogy in and for the age of the network. Philosophy of Education, 14(1), 106-126; and McLaren, P. \& Jandrić, P. (2014). Kultura borbe protiv neoliberalnog kapitalizma. Zarez, 398-99(16), 8-9. Reprinted parts of the text have been reformatted, abridged, and otherwise reshaped for the purpose of this article.

\section{References}

Anderson, K. (2010). Overcoming Some Current Challenges to Dialectical Thought. International Marxist-Humanist, 18 August 2010. http://www.internationalmarxist humanist.org/wp-content/uploads/pdf/anderson-overcoming-some-current -challenges-to-dialectical-thought-20100818.pdf. Accessed 14 December 2018.

Black, D. (Ed.) (2014). Helen MacFarlane: Red Republican: Essays, Articles and Her Translation of the Communist Manifesto. London: Uncant Publishers.

Boal, A. (2008). Theatre of the Oppressed (Get Political). London: Pluto Press.

Boff, L. (1982). Francis of Assisi: A Model of Human Liberation. Trans. J.W. Diercksmeier. Maryknoll, NY: Orbis Books.

Boff, L. (1986). Ecclesiogenesis: the base communities reinvent the church. Maryknoll, NY: Orbis Books. 
Collier, A. (2001). Christianity and Marxism: A Philosophical Contribution to their Reconciliation. London: Routledge.

De La Torre, M. (2015). The Politics of Jesús: A Hispanic Political Theology. Lanham: Rowman and Littlefield.

Eagleton, T. (2009). Reason, Faith and Revolution: Reflections on the God Debate. New Haven, CT, and London: Yale University Press.

Freire, P. (1972). Pedagogy of the Oppressed. Harmondsworth: Penguin Education Specials.

Gutierrez, G. (1988). A Theology of Liberation: History, Politics, and Salvation. Trans. C. Inda and Eagleson J. Maryknoll, NY: Orbis Books.

Hardt, M. \& Negri, A. (2001). Empire. Cambridge, MA: Harvard University Press.

Holloway, J. (2016). In, against, and beyond Capitalism: The San Francisco Lectures. Oakland, CA: PM Press/Kairos.

Lebacqz, K. (1986). Six Theories of Justice: Perspectives from Philosophical and Theological Ethics. Minneapolis, MN: Augsburg.

Marx, K. (1981). Capital, Vol. III. New York: Vintage.

Marx, K. (1955). The poverty of philosophy - Answer to the philosophy of poverty by M. Proudhon. Moscow: Progress.

Marx, K. \& Engels, F. (1976). The Communist Manifesto. In Marx-Engels-CollectedWorks (MECW), Volume 6. https://www.marxists.org/archive/marx/works/1848/ communist-manifesto/index.htm. Accessed 3 January 2018.

Marx, K. (1976). Theses on Feuerbach. In Marx-Engels-Collected-Works (MEcW), Volume 5. http://marxists.anu.edu.au/archive/marx/works/1845/theses/original. htm. Accessed 3 January 2018.

McLaren, P. (1999). Schooling as a Ritual Performance: Towards a Political Economy of Educational Symbols and Gestures. Lanham, MD: Rowman \& Littlefield.

McLaren, P. (2015). Pedagogy of Insurrection: From Resurrection to Revolution. New York: Peter Lang.

McLaren, P. (Ed.) (2006). Rage and Hope: interviews with Peter McLaren on war, imperialism, and critical pedagogy. New York: Peter Lang.

McLaren, P., McMurry, A. \& McGuirk, K. (2008). An Interview with Peter McLaren. Waterloo: University of Waterloo. http://english.uwaterloo.ca/PeterMcLareninterview.pdf. Accessed 3 January 2018.

Miranda, J.P. (1977). Being and the Messiah: The Message of St. John. Maryknoll, NY: Orbis Books.

Miranda, J.P. (2004). Communism in the Bible. Trans. RR Barr. Eugene, OR: Wipf \& Stock. Miranda, J.P. (1980). Marx against the Marxists: The Christian Humanism of Karl Marx. Trans. J. Drury Maryknoll, NY: Orbis Books.

Hinnem, N. (2013). Marx and the Bible. The Oxford Left Review, 11, 31-37.

Rivage-Seul, M. (2008). The Emperor's God: Imperial Misunderstandings of Christianity. Radford, VA: Institute for Economic Democracy Press. 
Rosen, M. (2000). The Marxist Critique of Morality and the Theory of Ideology. In E. Harcourt (Ed.), Morality, Reflection and Ideology (pp. 21-43). Oxford: Oxford University Press.

Sobrino, J. (2001). Christ the Liberator. Maryknoll, NY: Orbis Books.

Turner, D. (1983). Marxism and Christianity. Oxford: Blackwell. 